\title{
Corrigendum: Advances in Plant-Derived Scaffold Proteins
}

\section{OPEN ACCESS}

Approved by:

Frontiers Editorial Office,

Frontiers Media SA, Switzerland

*Correspondence:

Congyue Annie Peng congyup@clemson.edu

William R. Marcotte $\mathrm{Jr}$ marcotw@clemson.edu

Specialty section This article was submitted to

Plant Biotechnology

a section of the journal

Frontiers in Plant Science

Received: 13 September 2021 Accepted: 22 September 2021

Published: 08 October 2021

Citation: Peng CA, Kozubowski L and Marcotte WR Jr (2021) Corrigendum: Advances in Plant-Derived Scaffold Proteins.

Front. Plant Sci. 12:775296 doi: $10.3389 / f p / s .2021 .775296$

\section{Congyue Annie Peng *, Lukasz Kozubowski and William R. Marcotte Jr*}

Department of Genetics and Biochemistry, Clemson University, Clemson, SC, United States

Keywords: spider silk, collagen, elastin, scaffold, regenerative medicine, extracellular matrix

\section{A Corrigendum on}

\section{Advances in Plant-Derived Scaffold Proteins}

by Peng, C. A., Kozubowski, L., and Marcotte, W. R. Jr. (2020). Front. Plant Sci. 11:122. doi: $10.3389 /$ fpls.2020.00122

In the original article, the authors neglected to include that this project was funded in part by Clemson University's R-Initiative Program to William R. Marcotte Jr.

The authors apologize for this error and state that this does not change the scientific conclusions of the article in any way. The original article has been updated.

Publisher's Note: All claims expressed in this article are solely those of the authors and do not necessarily represent those of their affiliated organizations, or those of the publisher, the editors and the reviewers. Any product that may be evaluated in this article, or claim that may be made by its manufacturer, is not guaranteed or endorsed by the publisher.

Copyright ( $\odot 2021$ Peng, Kozubowski and Marcotte Jr. This is an open-access article distributed under the terms of the Creative Commons Attribution License (CC BY). The use, distribution or reproduction in other forums is permitted, provided the original author(s) and the copyright owner(s) are credited and that the original publication in this journal is cited, in accordance with accepted academic practice. No use, distribution or reproduction is permitted which does not comply with these terms. 